\title{
OBITUARY
}

\section{César Ades (08.I.1943 - 14.III.2012)}

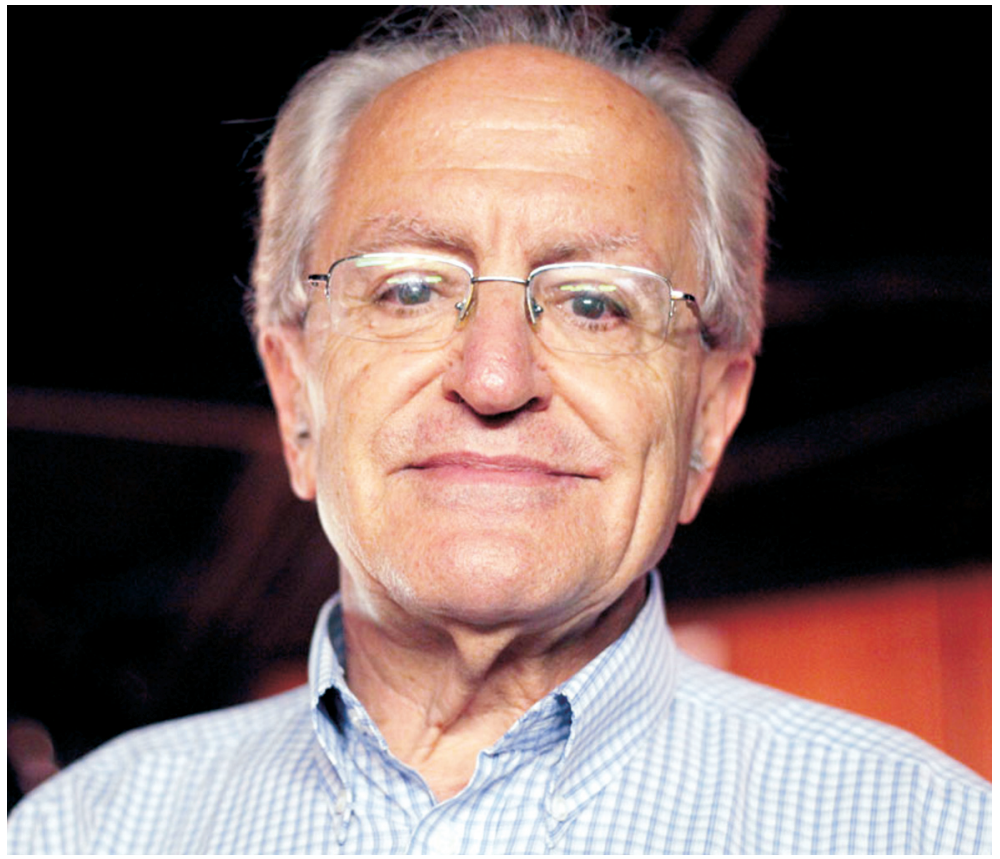

César Ades, 2012. Photo by Lia Ades Gabbay.

Escrever sobre uma pessoa de personalidade tão carismática, de vida tão rica em experiências, e de trajetória tão profícua como o César não é fácil. Seu caminho profissional ao longo de 47 anos explica em boa parte o desenvolvimento dos estudos e a formação de profissionais atuantes na área de comportamento animal no Brasil. Nos conhecemos em 1993, e a partir de 1994 iniciei o Doutorado sob sua orientação, no Instituto de Psicologia da Universidade de São Paulo (USP). Acho que uma relação passional com a indagação define em parte sua trajetória, que envolveu investigação e orientação de trabalhos sobre quase 60 espécies de insetos, aranhas, mamíferos (Homo sapiens incluso!). Dentre suas variadas publicações, encontram-se "A dog at the keyboard: using arbitrary signs to communicate requests" (2008), "O morcego, outros bichos e a questão da consciência animal" (1997), "Experimental studies of elementary reasoning: evolutionary, physiological and genetic aspects of behavior" (1992), "O que aprendem e de que se lembram as aranhas" (1989) e "Entre Eidilos e Xenidrins: experiência e pré-programas no comportamento humano" (1986). Dizia por vezes "minha linha de pesquisa é a curiosidade", quando lhe indagavam sobre o currículo tão eclético. Orientou 34 projetos de Mestrado e 22 de Doutorado, 15 Trabalhos de Conclusão de Graduação, 72 Iniciações Científicas. Seus orientandos tinham diversas forma-
It is not easy to write about someone whose personality was so charismatic, whose life was filled with such a wealth of experience and whose career was of such value, as César. His professional career, which lasted 47 years, largely accounts for the way in which studies in Brazil have developed in the area of animal behavior, and the training of practicing professionals. We got to know each other in 1993, and in 1994 I began my doctorate under his supervision at the Institute of Psychology, University of São Paulo (USP). I think that the course of his career can be partly defined as a passionate concern with inquiry. It involved research and supervision of projects on almost 60 species of insects, spiders and mammals (including Homo sapiens!). Among his various publications, the following are highlighted "A dog at the keyboard: using arbitrary signs to communicate requests" (2008); "The bat, other animals, and the question of animal consciousness" (1997); "Experimental studies of elementary reasoning: evolutionary, physiological and genetic aspects of behavior" (1992); "What spiders learn and what they remember" (1989) and "Between Eidilos and Xenidrins: experience and pre-programming in human behavior" (1986). When asked about his eclectic curriculum, César would sometimes say: "my line of research is curiosity". He supervised 34 Master's theses and 22 doctoral studies, 15 graduation final projects and 72 undergraduate researches. The students he supervised had several professional backgrounds. 
ções profissionais. Segundo César, "beneficiei-me muito em conviver com biólogos, veterinários e zootecnistas, antropólogos e psicólogos, para a construção do conhecimento a respeito do comportamento. O surgimento da Etologia no Brasil se caracteriza como um empreendimento a várias mãos" (Kinouchi \& Ramos 2011: Scientiae Studia 9 (1): 189-203). Foi professor titular do Instituto de Psicologia da USP (1994), vicediretor (1998-2000) e depois diretor (2000-2004) dessa mesma unidade; diretor do Instituto de Estudos Avançados da USP (2008-2012), entre vários outros cargos administrativos e consultivos na USP e em outras várias instituições.

Um quinhão do que relato aqui são memórias de nossas conversas e convivência, em uma relação de orientação de doutorado que se estendeu para amizade. Apresento também excertos de seu pensamento, retirados de uma entrevista recente (Kinouchi \& Ramos 2011). César Ades, um dos filhos de Céline e Tewfik, nasceu em oito de janeiro de 1943 no Cairo e viveu no Egito com sua irmã Mireille e seu irmão Alberto até 1958, estudando em escolas francesas no Egito e no Liceu Pasteur, no Brasil. César relatava seu grande interesse pela natureza desde sempre, acampando e fazendo trilhas, várias vezes acompanhado pelo primo Sezar Sasson, que se tornou biólogo pela USP, coautor de vários livros amplamente adotados de Biologia para Ensino Médio, e professor e autor de material didático no Anglo Vestibulares de São Paulo (onde fui seu aluno em 1986). Sasson relatou que César lia desde criança no Egito com muito interesse a coleção de livros do naturalista francês Jean-Henri Fabre, "Souvenirs entomologiques". Aluno brilhante de Psicologia, ainda nos tempos da USP Maria Antônia com laboratórios em porões do prédio antigo, iniciou seu trabalho de pesquisa, publicando seu primeiro artigo no final da graduacão (1965). No mesmo ano iniciou suas atividades docentes; contava que chegou a ministrar aulas a alunos desperiodizados de sua turma de graduação. Realizou seu Mestrado (1969) sob a orientação de Dora Selma Fix Ventura, depois sua colega na USP, sobre comportamento de ratos de laboratório. Seu Doutorado (1973), orientado pelo pioneiro da Etologia no Brasil, Walter Hugo de Andrade Cunha, versou sobre a teia e a caça da aranha Argiope argentata (Fabricius, 1775). Sobre o Doutorado, escreveu César: "Um dia Walter Cunha me trouxe, numa caixa de sapatos, uma belíssima aranha de teia que, em consulta ao pessoal do Butantã, soube tratar-se de Argiope argentata. Esta aranha trazia de volta minha primeira experiência como naturalista amador. Com 13 anos de idade, em um jardim de Alexandria, inspirado na leitura do livro La vie des araignées de Jean-Henri Fabre [...] eu ia vendo como uma aranha orbitela caçava os insetos que eu depositava na teia e como se livrava de folhas ou gravetos". Sobre o orientador: "Walter foi um interlocutor essencial. Vali-me especialmente de sua abordagem do comportamento animal, ao mesmo tempo rigorosa e detalhista, e também aberta para a dimensão crítica, teórica". César interagiu com grandes expoentes do behaviorismo, mas como me disse, várias indagações ficavam sem resposta, e sua
According to César: "I have benefited a great deal from working together with biologists, veterinarians and zootechnicians, anthropologists and psychologists to build up knowledge about behavior. The rise of Ethology in Brazil can be characterized as a shared undertaking involving various people" (KINOUCHI \& Ramos 2011: Scientiae Studia 9 (1): 189-203). He was a Fellow at the Institute of Psychology at USP (1994), Vice-Director (1998-2000) and later Director (2000-2004) at the same Institute; Director of the Institute of Advanced Studies, USP (2008-2012), among several other administrative and advisory responsibilities at USP and various other institutions.

A part of what I recall here consists of memories of our conversations and shared experience of our advisor-student relationship, which became a friendship. I also include some excerpts of comments he made in a recent interview (KINOUCHI \& Ramos 2011). César Ades, one of the children of Celine and Tewfik, was born in Cairo on January 8, 1943, and lived there with his sister Mireille and brother Alberto until 1958. César studied in French schools while in Egypt, and at the Pasteur Lycee in Brazil. According to him, he had always had a great interest in nature, and used to go on camping and walking trips in the countryside. He was often accompanied by his cousin Sezar Sasson, who graduated as biologist at USP and has co-authored several books that have been widely used in Middle and High School Biology classes in Brazil. Sasson is also a teacher and author of teaching materials at Anglo Vestibulares in São Paulo (where I was his student in 1986). According to Sasson, when César was a child growing up in Egypt, he was very interested in reading the collection of books by the French naturalist JeanHenri Fabre called "Souvenirs entomologiques" He was a brilliant student of Psychology, at the times of the USP Maria Antonia campus, when there were laboratories in the basement of an old building. He began his research career back then by publishing his first article before graduating in 1965. In the same year, César began his teaching activities; he told us that he got to lecture his former colleagues who had been held back from his graduation class. He obtained his Master's degree (1969) under Dora Selma Fix Ventura, who later became his colleague at USP; his thesis was on the behavior of laboratory rats. His Ph.D. dissertation (1973), under Walter Hugo de Andrade Cunha, the pioneer of Brazilian Ethology, was about the web and the predatory behavior of the spider Argiope argentata (Fabricius, 1775). About his doctorate, César wrote: "One day Walter Cunha brought me a lovely spider web in a shoe-box. After consulting Butantã Institute specialists, I found out that spider was Argiope argentata. This spider reminded me of my first experience as an amateur naturalist. At the age of 13, in a garden of Alexandria, and inspired by the book La vie des araignées by Jean-Henri Fabre [...] I used to observe how a orbicular spider hunted the insects that I had placed in her web and how she got rid of leaves or brushwood." About his advisor: "Walter was a quintessential interlocutor. I particularly valued his approach to animal behavior. He was both rigorous and meticulous but in the same time willing to adopt a critical, theoretical dimension". César interacted 
empatia "etológica" com os animais a campo lhe fazia ver que muito mais havia a explorar. Essa inquietação estava presente desde cedo: "É significativo que meu contato com o comportamento animal, na graduação, tivesse se dado tanto pelo aspecto da aprendizagem e da cognição quanto pelo dos mecanismos instintivos. A possibilidade de que ambos pudessem ser integrados em uma concepção unificada a respeito do comportamento já constituía motivo de reflexão [...] Mantive sempre o fascínio pela capacidade que animais (e seres humanos) têm de fazer o que fazem, ajustando-se ao contexto. Aristóteles se encantava com a capacidade de a aranha construir a sua teia, sinto o mesmo encanto".

Assim, sua trajetória na Etologia explica em boa parte o desenrolar desse ramo do conhecimento no Brasil, sendo seu grande catalizador e fulcro, sem dúvida. Na Sociedade Brasileira de Etologia (SBEt) foi fundador, depois presidente por duas vezes (1994-1996 e 1996-1998) e participante em vários cargos da diretoria em diferentes gestões. A SBEt promove o Encontro Anual de Etologia, que em 2012 chega às sua trigésima edição, sempre com muitos participantes. César sempre estava presente e atuante nesses encontros. Foi membro do International Council of Ethologists e da International Society of Comparative Psychology. Em 2003, coordenou a $28^{\text {th }}$ International Ethological Conference, da International Society of Comparative Psychology. Editor desde 1999 e um dos fundadores da Revista de Etologia e membro do conselho editorial dos periódicos Behavior and Philosophy e Acta Ethologica. O entusiasmo contagiante do César, seu bom humor, suas palestras memoráveis e seu apoio a tudo que envolvesse a Etologia eram patentes. Com interesses variados, sólida cultura clássica e mente inquiridora afiada, uma conversa sobre ciência com ele era sempre um aprendizado. Segundo Sasson, "Uma característica marcante da personalidade do César era a "generosidade intelectual", que definiria a disposição a ouvir, a compreender a opinião e a posição do outro. Outra característica marcante, a meu ver, era sua constante disposição em ajudar as pessoas, conversando, sugerindo [...]. Pessoalmente, me ajudou muito em decisões difíceis, que de certa forma definiram vários de meus rumos como pessoa e como profissional".

Escreveu César: "A interdisciplinaridade [...] contribui para a criatividade e a flexibilidade da construção do conhecimento. No contexto da descoberta, no dia a dia da pesquisa, vale a tentativa de ir além dos métodos e das teorias (sem deixar de segui-los), recorrendo a táticas que instauram propositadamente variação. A variação envolve algum desvio em relação à prática estabelecida". Como escreveu Francisco Dyonisio C. Mendes, professor da Universidade de Brasília e meu contemporâneo no Doutorado (Mendes 2012: http:// scienceblogs.com.br/socialmente/2012/03/uma-homenagemao-mestre-cesar-ades): "quase causava estranheza como dominava tantos assuntos com tanta facilidade". César para mim representava o verdadeiro sentido da palavra PhD: se não era um doutor em filosofia, era um doutor com bagagem filosófi- with the leading exponents of behaviorism but, as he told me, a lot of his inquiries remained unanswered, and his "ethological" empathy for animals in the field made him see that there is much more to explore. César felt this anxiety early on in life: "It's significant that my contact with animal behavior when I was a graduate student was manifested by cognitive learning as much as by instinctive mechanisms. The prospect of combining both in a unified concept with regard to behavior provided grounds for reflection [...]. I have remained fascinated by the capacity that animals (and human beings) have to do what they do, and adapt to their context. Aristotle was enchanted with the ability of the spider to spin its web, and so am I".

César's career in Ethology largely explains how this branch of knowledge unfolded in Brazil. He was, without doubt, the great catalyst and fulcrum of his field. He was one of the founders of the Brazilian Society of Ethology (SBEt) and twice President of it (1994-1996 and 1996-1998). Furthermore, he took on several responsibilities in different management boards. The SBEt organizes the Annual Meeting of Ethology which, in 2012, will hold its $30^{\text {th }}$ edition, always with a large number of participants. César always actively participated in these meetings. He was a member of the International Council of Ethologists and the International Society of Comparative Psychology. He was also one of the founders of the Revista de Etologia and remained as its Editor since 1999. He was also a member of the editorial board of the periodicals Behavior and Philosophy and Acta Ethologica. César's contagious enthusiasm was always evident, as was his good sense of humor, his memorable lectures, and his support for everything that involved Ethology. With his wide range of interests, solid classical background and sharp inquiring mind, it was always intellectually stimulating to have a conversation about science with him. According to Sasson, "One striking feature of César's personality was his "intellectual generosity", which can be defined as a willingness to listen to and understand the opinions and standpoint of others. Another of his notable characteristics, in my view, was his readiness to help people by listening to them and making suggestions [...]. Personally, he helped me a lot when I was making difficult decisions. To some extent, those decisions have determined several of my life paths, both as a person and as a professional.

César wrote: "Interdisciplinarity [...] leads to creativity and flexibility in building knowledge. In the area of discovery, during the day-to-day research, it is worth attempting to go beyond methods and theories (though without ceasing to follow them) and resort to tactics that deliberately lead to variety. The latter involves some form of deviation from pre-established practices". In the words of Francisco Dyonisio C. Mendes, teacher at the University of Brasilia and my contemporary during my doctorate (MeNDES 2012: http://scienceblogs.com.br/socialmente/2012/03/ uma-homenagem-ao-mestre-cesar-ades): "it was almost strange how he was able to master so many subjects with such ease". In my view, César embodied the real meaning of the term PhD; if he was not a doctor of philosophy, he was a doctor with philosophic baggage and was not limited to just one possible interpretation, 
ca e não viciada em apenas um viés interpretativo, algo difícil de se encontrar atualmente. Ficava bravo quando dizíamos brincando que se a Etologia fosse o SBT, ele seria o Sílvio Santos. Era presença constante na mídia, quando o tema era comportamento animal. Tinha fluência no inglês e espanhol, também no árabe e no francês, além de "arranhar" em várias outras línguas. Gostava muito de música, e compartilhávamos nosso errático empenho e parco sucesso no domínio da gaita diatônica. Adorava gravuras, pintura, teatro e fotografia. Um dia encontrou meu irmão que é engenheiro civil, e conversaram com entusiasmo sobre a urbanização de São Paulo. Sempre me pedia para encontrá-lo de novo, pois o tema lhe interessava muito. Uma visita à sua casa mostrava o quanto a pesquisa, a cultura, os livros, lhe eram caros. Muitas estantes repletas de centenas, arrisco milhares de livros sobre variadíssimos temas, teses, revistas, manuscritos... Por outro lado sua frugalidade sempre me impressionou. Pessoa refinada em termos de educação, de fala, de modos, de senso estético, mas muito informal e "básico" em hábitos de consumo. Não dirigia automóveis, e quando lhe perguntei o porquê, sua resposta deixou antever que preferia investir na família e cultura ao invés de automóveis... Sua relação com as duas filhas Lia e Tatiana era muito estreita, carinhosa, e de corujice explícita. As poucas vezes que o vi emocionado ao falar foram após visitas à sua mãe, acometida pelo Mal de Alzheimer.

César prezava muitíssimo a atividade de ensino. Segundo Vera Bussab, colega de departamento "Ades era uma pessoa cativante, envolvente. Sempre acolhia com entusiasmo as novas questões e tinha diversos ângulos para retratar e olhar os temas em estudo. Raramente se vê um professor com capacidade de envolvimento, buscando sempre fomentar a curiosidade do aprendiz" (Leão 2012: http://espaber.uspnet.usp.br/ jorusp/?p=21123). Seus cursos e palestras ficaram famosos pela primorosa preparação, simpatia, bom humor e pelos textos de apoio, em sua maioria de autoria própria. Sua presença nos Encontros de Etologia, no contato caloroso com estudantes, fazia toda a diferença. Sua receptividade às novas idéias, vindas de estudantes ou colegas, e ao mesmo tempo sua análise crítica profunda mas polida, eram um grande estímulo ao debate. Milhares de páginas de textos acadêmicos foram produzidas por César ao longo de sua vida, basta mencionar seus 123 artigos científicos, quatro livros, 25 capítulos de livros entre muitos outros textos. No entanto, ele não tinha uma obsessão do tipo "publish or perish" e sobre esse tema, escreveu: "Há aspectos positivos e aspectos negativos da corrida às publicações. Positiva é a necessidade de colocar os resultados de pesquisa num foro amplo, à disposição de quem quiser se interessar, seguindo as regras que regem esse tipo de comunicação. A pressão para publicar corrige uma certa acomodação docente a níveis restritos de divulgação. Por que não um público mais vasto e leitores mais exigentes? A ciência se configura cada vez mais como empreendimento internacional, desenvolve exigências de publicação pronta e frequente e isso vale para a produção científica brasileira [...] Negativos são os something which is difficult find these days. He was serious when he said jokingly that if Ethology was SBT, he would be Sílvio Santos. He was constantly in the media, whenever the subject was animal behavior. He was fluent in English, Spanish, Arabic and French, and had a "smattering" of several other languages. He liked music a lot and we shared our erratic interest, and limited success in mastering the harmonica. He was very keen on engravings, paintings, the theater and photography. One day he met my brother, who is a civil engineer, and they had a lively conversation about the urbanization of São Paulo. César asked me several times if he could meet my brother again, because the subject interested him so much. A visit to his house showed how much research, culture and books were dear to him. There were a lot of shelves full of hundreds, or dare one say, thousands of books about a huge range of subjects; dissertations, magazines, manuscripts and so on. On the other hand, his frugality also impressed me. Although he was sophisticated with regard to education, conversation, behavior and had a keen esthetic sense, he was very informal and "basic" in his consumer habits. He did not drive and when I asked him why, his reply made it clear that he preferred to invest on his family and on cultural maters than on cars... His relationship with his two daughters Lia and Tatiana was very warm and close, and openly affectionate. The few occasions when I saw him speak in an emotional way was after his visits to his mother, who suffered from Alzheimer's disease.

César highly valued teaching activities. According to Vera Bussab, a colleague in his department: "Ades was a fascinating person who was very involved in everything. He would always welcome any new topic with enthusiasm, and was able to look at his subjects of study from various angles. It is rare to find a professor with such capacity for involvement, and who is always seeking to foster a real curiosity in the learner" (LEÃo 2012: http://espaber.uspnet.usp.br/jorusp/?p=21123). His courses and lectures were renowned for their meticulous preparation, friendliness and sense of humor, and their supporting texts, most of which had been written by himself. His presence at Ethology meetings made all the difference, because of the warmth he displayed towards the students. While he was receptive to new ideas, whether coming from students or colleagues, his polished, indepth analyses were a great stimulus in a debate. Thousands of pages of academic texts were produced by César throughout his life: 123 papers, 4 books, 25 book chapters among many other texts. Nonetheless, he was not obsessed with the "publish or perish" motto, and wrote the following about it: "There are both positive and negative aspects in the publication frenzy. On the positive side, there is a need to place the results of a research study in a broader forum, so that they can be at the disposal of anybody who is interested, while being in compliance with the rules that govern this kind of communication. The pressure to publish also corrects a tendency among academics to disseminate their work at a restricted level. Why not a much larger public and more demanding readers? Science is increasingly expanding to an international undertaking that requires rapid and frequent publications; this is also true for the scientific pro- 
efeitos colaterais: uma quantificação exclusiva, ou quase, do mérito por número de publicações, estratégias de multiplicação de trabalhos e autorias, critérios afunilados de progressão horizontal na carreira, um espírito de competição e produtividade capaz de prejudicar a curiosidade solta, a busca da relevância e originalidade conceitual, a tomada de riscos que leva à inovação. Alguma margem para a pesquisa e a reflexão despreocupadas tem que existir na universidade, às vezes penso que este é um dos papéis de um Instituto de Estudos Avançados." Sobre seu incansável entusiasmo pela pesquisa: "Entrar em contato com algo que a gente não conhece, algo que ocorre de forma autônoma e que segue princípios próprios, é o primeiro gosto (quase metafísico) que a pesquisa proporciona [...] No caso da etologia, observar bastante e pacientemente faz com que a gente entenda o 'jeito' próprio do animal em relação ao seu ambiente próprio, ao seu Umwelt. Não se trata de interpretá-lo como igual à gente, mas de ir em direção a ele [...] O segundo prazer da pesquisa tem a ver com a representação abstrata, teórica, que a gente constrói e que passa a ser um guia, e nos leva além da pura descrição. O tempo todo, estamos rastreando e cercando idéias, construindo modelos, imaginando o real a partir dele próprio. É um vai-e-vem entre a informação coletada e a hipótese, sobressaltos ocorrem quando vemos desmentida uma idéia, euforia quando a idéia é confirmada ou quando, desistindo dela, aventamos outra maneira de dar conta das coisas [...] Esta excitação de descobrir tem me acompanhado ao longo de uma longa carreira, nunca deixo de me surpreender com resultados obtidos em meu laboratório ou com a informação que eu obtenho todos os dias nas bases bibliográficas da Internet."

Citando Mendes (2012): “César viveu por 69 anos como quis: intensamente e produzindo conhecimento! [...] Não é exagero dizer que a Etologia brasileira foi em grande parte construída por ele, dentro do Departamento de Psicologia Experimental da USP. Foi ali que ele formou a maioria dos etólogos e psicólogos evolucionistas que atuam hoje no Brasil, que mostrou para biólogos a importância de entender o comportamento dos animais, e para psicólogos a relevância da teoria evolutiva para a compreensão do comportamento humano [...] César deixou não só seus planos, mas um legado de alunos e admiradores que levarão adiante seus ensinamentos. Obrigado, César, por sua contribuição para a Etologia e Psicologia brasileira... e muito obrigado por ter ensinado a tanta gente como viver com ética, curiosidade, alegria e paixão pela vida."

Pela minha parte, muitas saudades e um profundo agradecimento ao mestre e amigo. duction in Brazil. The negative, collateral effects, are as follows: an assessment of merit based almost, if not entirely, on the number of publications; strategies to increase the number of studies and authors; narrow criteria determining the horizontal advancement in a research career; a spirit of competitiveness; and a desire for productivity that can have a harmful effect on free inquiry, the search for significance and conceptual originality, and on the willingness to take risks leading to innovation. There must be space for research and disinterested reflection in universities; sometimes, I think that this is one of the roles of an Institute for Advanced Studies. With regard to his tireless enthusiasm for research: "entering in contact with something that we don't know, something that occurs in an autonomous way and which follows its own principles, is the first (almost metaphysical) taste of research [...] In the case of ethology, close and patient observation enables us to understand the specific "knack" of the animal in relation to its own environment, to its Umwelt. It is not a question of seeing the animal as equal to us, but to move towards it. A further pleasure of research lies in the abstract theoretical representation, which is constructed and can serve as a guide to take us beyond the realm of pure description. The entire time we explore and contextualize ideas, devise models and imagine the real from the thing itself. It is a give-and-take process between collected information and a hypothesis; we are shocked when we find an idea refuted and overjoyed when it is proved to be true, or after giving it up, we are able to go forward in another way to give provide an alternative account of things. [...] This excitement of making a discovery has accompanied me throughout a long career; I have never ceased to be surprised by the results obtained in my laboratory or with information I obtain every day from bibliographical databases on the Internet".

Quoting Mendes (2012):" César lived for 69 years the way that he wanted - intensely and producing knowledge! [...] It is no exaggeration to say that Brazilian Ethology was largely constructed by him inside the Department of Experimental Psychology at USP. It was there that he formed most ethologists and evolutionary psychologists that work in Brazil today, and where he showed biologists the importance of understanding the behavior of animals; and psychologists, the significance of the theory of evolution for the understanding of human behavior. [...] César not only left us his projects, but also a legacy of students and admirers who will take his teachings forward. Thank you César for your great contribution to Ethology and Brazilian Psychology... and our deepest thanks for having taught people to live in an ethical way with curiosity, delight and a passion for life".

For my part, I feel a real sense of gratitude to a master and friend whom I will deeply miss.

\section{Eduardo Novaes Ramires}

Post-doctorate, Departamento de Zoologia, Universidade Federal do Paraná. Caixa Postal 19020, 81531-980 Curitiba, PR, Brazil.E-mail: eduramires@yahoo.com

ZOOLOGIA 29 (3): 280-284, June, 2012 